\title{
PERANCANGAN ALAT PENYEMPROT HAMA TANAMAN TIPE KNAPSACK BERBASIS SOLAR PANEL 20 WP
}

\author{
Efrizal, Johan Sainima \\ Program Studi Teknik mesin, Fakultas teknik, Universitas Muhammadiyah Tangerang, \\ Jl. Perintis Kemerdekaan I, No.33, Cikokol, Tangerang, Banten 15118, Indonesia \\ E-mail : efrizal.arifin@gmail.com dan jsainima7@gmail.com
}

\begin{abstract}
ABSTRAK
Alat penyemprot tanaman (sprayer) adalah alat/ mesin yang berfungsi untuk memecah suatu cairan, larutan menjadi butiran cairan (droplets). Beberapa tahun terakhir ini energi merupakan persoalan yang krusial didunia. Peningkatan permintaan energi yang disebabkan oleh pertumbuhan populasi penduduk dan menipisnya sumber cadangan minyak dunia serta permasalahan emisi dari bahan bakar fosil memberikan tekanan kepada setiap negara untuk segera menggunakan Renewable Energy maupun energi alternatif. Panel surya Fotovoltaik atau solar cell adalah alat untuk mengkonversi tenaga matahari secara langsung menjadi energi listrik. Pentingnya pengetahuan tentang kondisi di dunia serta perkiraan hal yang akan terjadi di masa depan dapat menunjang keberhasilan seseorang membuat ataupun rancang bangun alat - alat yang sangat mempermudah manusia dalam berbagai aspek kehidupan. Kini telah dibuat alat penyemprot hama berbasis modul PV, alat ini menggunakan energi matahari sebagai sumber tenaganya. Dari hasil pengamatan dan analisa dari alat penyemprot hama berbasis modul PV ini mampu bekerja lebih lama, peningkatan persentase pemakaian alat ini mencapai $42,86 \%$
\end{abstract}

Kata Kunci: Perancangan, alat, penyemprot hama, knapsack, solar panel

\section{PENDAHULUAN}

Seiring dengan perkembangan zaman dan teknologi di era globalisasi yang menuntut manusia untuk mengikuti laju perkembangan zaman, dimana disetiap aspek dituntut untuk memenuhi kebutuhan dan persaingan pasar yang semakin tinggi. Energi merupakan kebutuhan utama bagi umat manusia. Peningkatan kebutuhan energi dapat menjadi faktor peningkatan kemakmuran, tetapi juga dapat menimbulkan masalah dalam usaha penyediaannya. Dengan semakin menipisnya cadangan minyak bumi di Indonesia, pemanfaatan energi alternatif nonfosil harus ditingkatkan.Ada beberapa energi alam sebagai energi alternatif yang bersih, tidak berpolusi, aman dan persediaannya tidak terbatas yang dikenal dengan energi terbarukan. Diantaranya adalah energi surya, angin, gelombang dan perbedaan suhu air laut.

Upaya pencarian sumber energi baru sebaiknya memenuhi syarat yaitu menghasilkan jumlah energi yang cukup besar, biaya ekonomis dan tidak berdampak negatif terhadap lingkungan. Oleh karena itu pencarian sumber daya tersebut diarahkan pada pemanfaatan energi matahari baik secara langsung maupun tidak langsung dengan menggunakan alat penangkap sinar matahari yang dapat merubah energi matahari menjadi energi listrik yang dinamakanteknologi Panel Surya atau Solar Cell. Teknologi Solar Cell telah lama dikenal oleh manusia dibuat pertama kali oleh Charles Fritts pada tahun 1880, teknologi penangkap dan penyerap panas yang dibawah sinar matahari untuk diubah menjadi sumber energi listrik.

Indonesia merupakan negara yang membutuhkan pasokan energi yang cukup besar termasuk energi listrik. Untuk pemenuhan kebutuhan energi listrik dapat menggunakan sumber energi alternatif yaitu tenaga surya sebagai Pembangkit Listrik Tenaga Surya (PLTS). Sel surya (photovoltaic) merupakan piranti yang dapat mengkonversi cahaya matahari menjadi energi listrik. Energi surya adalah sumber energi yang dapat diperbaharui (renewable energy resources) yang sangat potensial. 
Energi surya dapat menghasilkan daya hingga 156.486 MW, jumlah yang lebih besar jika dibandingkan dengan sumber energi terbarukan yang lainnya. Indonesia merupakan negara yang terletak dalam jalur khatulistiwa yang sepanjang tahun mendapatkan cahaya matahari yang berlimpah.

\section{METODE PENELITIAN}

\section{A. Desain Penelitian}

Dalam penelitian ini, metode yang digunakan adalah studi literatur (kepustakaan), melakukan eksperimen dan melakukan pengamatan tentang alat penyemprot. Kemudian dilakukan perancangan pembuatan /perangkaian komponen-komponen alat. Setelah itu, dilakukan pengujian alat dan pengamatan parameter.

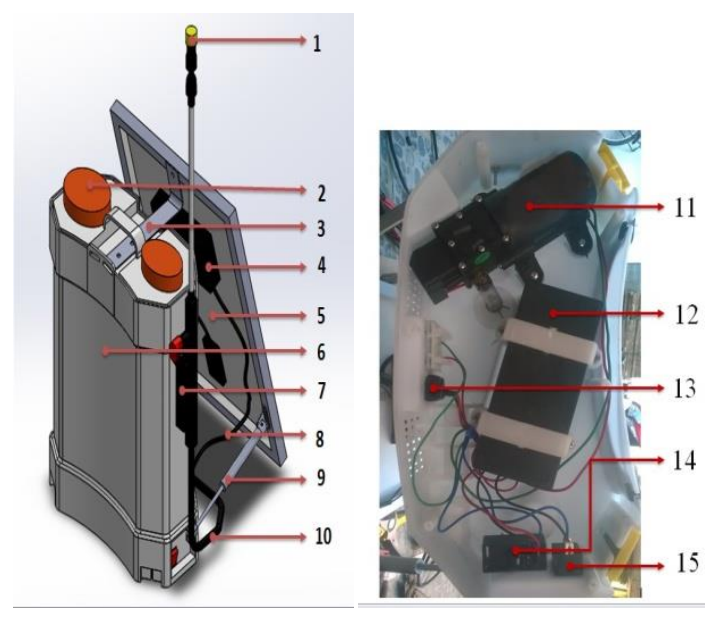

\section{Gambar 1. Alat penyemprot Hama Berbasis Solar Panel}

Keterangan :

1. Nosel (Nozzel)

2. Saringan (Strainer)

3. Besi Penopang

4. Charger Control

5. Panel Surya

6. Grip Pengatur Fluida

7. Tangki Penimpanan Fluida
8. Engsel Penyeimbang

9. Selang

10. Kabel Penghubung

11. Pompa

12. Baterai

13. Slot Baterai

14. Saklar ON/OFF Regulator Voltage

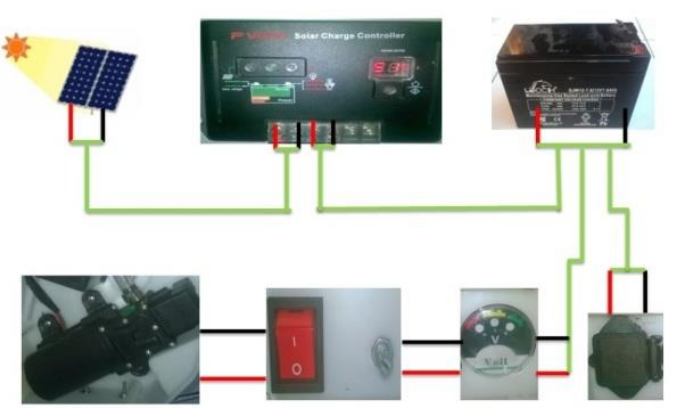

Gambar 2. Rangkaian Sistem Kelistrikan

Pengujian dilakukan di area/lahan terbuka yang terkena sinar matahari langsung. Adapun langkah-langkah dalam proses pengujian alat penyemprot hama berbasis solar panel 20WP adalah sebagai berikut :

1. Cek alat penyemprot hama apakah cara kerjanya masih berfungsi dengan baik dan normal.

2. Simulasikan posisi alat penyemprot hama/ Panel surya ke empat sudut arah mata angin, karena dalam penggunaan modul PV tidak bersifat tetap.

3. Cek indikator Charger Controller apakah terjadi pengisian arus pada baterai. Bila indikator menyala berarti terjadi pengisian arus pada baterai, apabila sebaliknya indikator mati berarti tidak ada pengisian arus pada baterai.

4. Ukur intensitas radiasi matahari yang masuk ke PV dengan alat ukur Lux Meter

5. Ukur arus tegangan yang masuk ke baterai melalui terminal pada Charger Controller. Pengukuran arus tegangan pada tiap posisi sudut arah mata angin.

6. Catat hasil pengukuran yang telah dilakukan untuk di masukan ke data Standart Test Condition.

7. Pengisian baterai, hal ini dilakukan bertujuan untuk mengetahui berapa lama waktu yang dibutuhkan untuk mengisi penuh daya baterai dengan menggunakan modul PV. 


\section{B. Metode Analisa Data}

Berikut adalah analisa dalam perakitan dan pengujian system :

$$
\mathrm{P}_{\text {in }}=\mathrm{I} \times \mathrm{A}
$$

Dimana :

$\mathrm{P}_{\text {in }}$ : Daya input akibat irradiance matahari (watt)

$\mathrm{I}_{\mathrm{r}} \quad$ : Intensitas radiasi matahari $\left(\mathrm{W} / \mathrm{m}^{2}\right)$

A : Luas area Permukaan modul PV $\left(\mathrm{m}^{2}\right)$

Sedangkan untuk besarnya daya sesaat pada panel surya yaitu perkalian tegangan rangkaian terbuka, arus hubungan singkat, dan Fill Factor yang dihasilkan oleh sel fotovoltaik dapat dihitung dengan persamaan rumus sebagai berikut(Journal Uji Ekpsperimental Pengaruh Sudut Kemiringan Modul Surya 50WP) :

$$
\mathrm{P}_{\max }=\mathrm{V}_{\mathrm{oc}} \times \mathrm{I}_{\mathrm{sc}} \times \mathrm{FF}
$$

Dimana :

$\begin{array}{ll}\mathrm{P}_{\max } & : \text { Daya PV (Watt) } \\ \mathrm{V}_{\mathrm{oc}} & : \text { Beda potensial (Volt) } \\ \mathrm{I}_{\mathrm{sc}} & : \text { Arus (Amp) } \\ \mathrm{FF} & : \text { Fill Factor }\end{array}$

Nilai FFdapat diperoleh dari rumus :

$$
\mathrm{FF}=\frac{\mathrm{V}_{\mathrm{mp}} \times \mathrm{I}_{\mathrm{mp}}}{\mathrm{V}_{\mathrm{oc}} \times \mathrm{V}_{\mathrm{sc}}}
$$

Dimana :

$\begin{array}{ll}\mathrm{FF} & : \text { Fill Factor } \\ \mathrm{V}_{\mathrm{mp}} & : \text { Max Power Voltage }(\text { Volt }) \\ \mathrm{I}_{\mathrm{mp}} & : \text { Max Power Current }(\text { Amp }) \\ \mathrm{V}_{\mathrm{oc}} & : \text { Open Circuit Voltage }(\text { Volt }) \\ \mathrm{I}_{\mathrm{sc}} & : \text { Short Circuit Current }(\mathrm{Amp})\end{array}$

Efisiensi yang terjadi pada sel surya adalah merupakan perbandingan daya yang dapat dibangkitkan oleh sel surya dengan energi input yang diperoleh dari sinar matahari. Efisiensi yang digunakan adalah efisiensi sesaat pada pengambilan data. Dengan Rumus (Studi Penggunaan Solar Reflector untuk Optimalisasi Output Daya pada Photovoltaic):

$$
\eta=\frac{P}{I_{r} \times A}
$$

Dimana :

$$
\begin{array}{ll}
\eta & \text { : Efesiensi Daya (Watt) } \\
\mathrm{P}_{\max } & \text { : Daya PV (Watt) } \\
\mathrm{I}_{\mathrm{r}} & : \text { Intensitas Radiasi }\left(1000 \mathrm{~W} / \mathrm{M}^{2}\right) \\
\mathrm{A} & : \text { Luas Penampang Panel Surya }\left(\mathrm{M}^{2}\right)
\end{array}
$$

\section{HASIL ANALISA DAN PEMBAHASAN}

\section{A. Analisa}

Untuk mengetahui daya yang masuk dari reaksi intensitas radiasi matahari, terlebih dahulu harus mengetahui Luasan dari penampang sel Modul PV dimana telah diketahui Panjang dari modul PV $500 \mathrm{~mm}$ dan Lebar nya $350 \mathrm{~mm}$, sementara panjang sel dari mudul PV adalah $430 \mathrm{~mm}$ dan Lebar 310 mm, maka Persamaan yang dipakai :

$$
\begin{aligned}
\mathrm{A} & =\mathrm{P} \times \mathrm{L} \\
& =430 \times 310 \\
& =133300 \mathrm{~mm}^{2} \\
& =0,133 \mathrm{~m}^{2}
\end{aligned}
$$

Daya sesaat yang dihasilkan kita harus mengetahui energi yang diterima, dimana energi tersebut adalah daya input dari perkalian intensitas radiasi yang diterima dengan luasan area modul PV dimana diketahui :

$$
\begin{aligned}
\mathrm{I}_{\mathrm{r}} & =1000 \mathrm{~W} / \mathrm{m}^{2} \\
\mathrm{~A} & =0,133 \mathrm{~W} / \mathrm{m}^{2}
\end{aligned}
$$

Maka persamaan yang dipakai :

$$
\begin{aligned}
\mathrm{P} & =\mathrm{I}_{\mathrm{r}} \times \mathrm{A} \\
& =1000 \times 0,133 \\
& =133 \text { Watt }
\end{aligned}
$$

Sedangkan untuk besarnya daya sesaat pada panel surya yaitu perkalian tegangan rangkaian terbuka, arus hubungan singkat, dan Fill Factor yang dihasilkan oleh sel fotovoltaik. Dimana nilai Fill Factor dapat dihitung dengan persamaan : 


$$
F F=\frac{V_{m p x} \times I_{m p}}{V_{o c x} \times I_{s c}}
$$

Dimana nilai :

$$
\begin{array}{ll}
\mathrm{V}_{\mathrm{mp}} & =17,4 \text { Volt } \\
\mathrm{I}_{\mathrm{mp}} & =1,16 \mathrm{Amp} \\
\mathrm{V}_{\mathrm{oc}} & =21,6 \mathrm{Volt} \\
\mathrm{I}_{\mathrm{sc}} & =1,27 \mathrm{Amp}
\end{array}
$$

Maka:

$$
\begin{aligned}
\mathrm{FF} & =\frac{17,4 \times 1,16}{21,6 \times 1,27} \\
& =0,73
\end{aligned}
$$

Dari yang telah diketahui maka :

$$
\begin{array}{ll}
\mathrm{V}_{\mathrm{oc}} & =21,6 \text { Volt } \\
\mathrm{I}_{\mathrm{sc}} & =1,27 \mathrm{Amp} \\
\mathrm{FF} & =0,73
\end{array}
$$

Maka :

$$
\begin{aligned}
\mathrm{P}_{\max } & =\mathrm{V}_{\mathrm{oc}} \times \mathrm{I}_{\mathrm{sc}} \times \mathrm{FF} \\
& =21,6 \times 1,27 \times 0,73 \\
& =21,02 \text { Watt }
\end{aligned}
$$

Efisiensi yang terjadi pada sel surya adalah merupakan perbandingan daya yang dapat dibangkitkan oleh sel surya dengan energi input yang diperoleh dari sinar matahari. Efisiensi yang digunakan adalah efisiensi sesaat pada pengambilan data.

Diketahui :

$$
\begin{array}{ll}
\mathrm{P} \max & : 20,02 \mathrm{Watt} \\
\mathrm{I} \mathrm{rad} & : 1000 \mathrm{~W} / \mathrm{m}^{2} \\
\mathrm{~A} & : 0,133 \\
\eta=\frac{\mathrm{P}_{\max }}{\mathrm{I}_{\mathrm{r}} \times \mathrm{A}} &
\end{array}
$$

Maka :

$$
\begin{aligned}
\eta & =\frac{20,02}{1000 \times 0,133} \times 100 \% \\
& =15,05 \%
\end{aligned}
$$

\section{B. Hasil Kerja Alat Penyemprot Hama}

Sebagian hasil kinerja dari alat penyemprot hama berbasis Modul PV dapat dilihat ketika melakukan pengujian pada modul PV tipe Polycristalline sesuai Standart Condition Testdapat diketahui efesiensi pada Modul PV mencapai 15,05\%, dimana nilai efesiensi standar dari Modul PV tipe Polikristal $13 \%-16 \%$. Dari hasil pengujian nilai efesiensi modul PV pada alat penyemprot hama diketahui mencapai nilai standar hal ini dapat menyebabkan nilai konversi energi listrik yang masuk ke baterai bisa optimal.

Keseluruhan hasil kinerja alat penyemprot hama berbasis mudul PV ini dapat di lihat dari hasil pengujian alat dalam bentuk tabel.

Tabel 1 : Kinerja Alat Penyemprot Hama Tanpa Mudul PV

\begin{tabular}{|c|c|c|c|c|c|c|c|c|}
\hline \multirow{2}{*}{ No } & \multirow{2}{*}{$\begin{array}{c}\text { Intensitas } \\
\text { Cahaya }\end{array}$} & \multicolumn{2}{|c|}{$\begin{array}{c}\text { Pane } \\
\text { l }\end{array}$} & \multicolumn{2}{|c|}{ Aki } & \multicolumn{2}{|c|}{ Beban } & \multirow{2}{*}{ Jam } \\
\cline { 3 - 8 } & & I & V & I & V & I & V & \\
\hline 1 & - & - & - & 7.2 & 12 & 2 & 12 & 3.5 \\
\hline
\end{tabular}

Tabel 2 : Kinerja Alat Penyemprot Hama Dengan Mudul PV

\begin{tabular}{|c|c|c|c|c|c|c|c|c|}
\hline \multirow{2}{*}{ No } & Intensitas & \multicolumn{2}{|c|}{ Panel } & \multicolumn{2}{|c|}{ Aki } & \multicolumn{2}{|c|}{ Beban } & \multirow{2}{*}{ Jam } \\
\cline { 3 - 8 } & Cahaya & I & V & I & V & I & V & \\
\hline 1 & 990 & 1 & 12,2 & 7.2 & 12 & 2 & 12 & 10 \\
\hline 2 & 942 & 2 & 12,20 & 7.2 & 12 & 2 & 12 & 11 \\
\hline 3 & 875 & 2 & 11,75 & 7.2 & 12 & 2 & 12 & 12 \\
\hline 4 & 640 & 1 & 11,75 & 7.2 & 12 & 2 & 12 & 13 \\
\hline 5 & 350 & 1 & 11,45 & 7.2 & 12 & 2 & 12 & 14 \\
\hline 6 & 178 & 1 & 11,07 & 7.2 & 12 & 2 & 12 & 15 \\
\hline \multicolumn{19}{|c|}{} \\
\hline
\end{tabular}

Dengan melihat tabel diatas dapat disimpulkan bahwa alat penyemprot hama mengalami kenaikan persentase kinerja pemakaian sebesar $42,86 \%$.

Tabel 3 : Pengukuran Radiasi Matahari Terhadap Sudut Kemiringan Panel Surya

\begin{tabular}{|c|c|c|c|c|c|c|c|c|}
\hline $\begin{array}{c}\text { Jam / } \\
\text { Sudut }\end{array}$ & 09 & 10 & 11 & 12 & 13 & 14 & 15 & 16 \\
\hline $10^{0}$ & 807 & 915 & 1054 & 980 & 973 & 720 & 540 & 330 \\
\hline $20^{0}$ & 875 & 920 & 1040 & 1006 & 930 & 641 & 364 & 250 \\
\hline $30^{0}$ & 910 & 932 & 1029 & 992 & 830 & 459 & 248 & 203 \\
\hline $40^{0}$ & 975 & 978 & 905 & 986 & 742 & 427 & 236 & 183 \\
\hline $50^{0}$ & 1007 & 980 & 945 & 855 & 782 & 410 & 215 & 152 \\
\hline $60^{0}$ & 1042 & 960 & 938 & 842 & 690 & 385 & 195 & 134 \\
\hline $70^{0}$ & 1070 & 990 & 942 & 875 & 640 & 350 & 178 & 115 \\
\hline $80^{0}$ & 1050 & 850 & 825 & 778 & 605 & 335 & 156 & 95 \\
\hline $90^{0}$ & 980 & 520 & 292 & 117 & 174 & 320 & 235 & 103 \\
\hline
\end{tabular}




\section{KESIMPULAN}

Hasil perancangan alat penyemprot hama berbasis modul PV 20WP dapat disimpulkan sebagai berikut :

1. Alat penyemprot hama ini menggunakan Modul Potovoltaik 20WP tipe Polycristalinesebagai alat untuk mengkonversi energi radiasi sinar matahari menjadi energi listrik untuk di supplay ke baterai sebagai sumber tenaga untuk menggerakan pompa. Dengan sistem kerja, fluida cair dikeluarkan dari tangki akibat dari adanya tekanan udara melalui tenaga pompa yang digerakan oleh baterai yang sumber tenaganya dari listrik hasil konversi energi sinar matahari melalui modul PV.

2. Modul PV pada alat penyemprot hama ini memiliki nilai persentase efesiensi sebesar $15,05 \%$. Sementara hasil kinerja alat penyemprot hama dengan modul PV mengalami peningkatan pemakaian dengan nilai persentase sebesar $42,86 \%$.

\section{DAFTAR PUSTAKA}

Abdul Kadir. 2010. Energi. Sumberdaya, Inovasi, Tenaga Listrik dan potensi Ekonom.Edisi 3.UI-Press : Jakarta.

AstuPudjanarso\&DjatiNursuhud. 2013. Mesin Konversi Energi. Edisi 3.C.V. AndiOffset : Yogyakarta.

Eflita Yohana, Darmanto. 2012. Uji Eksperimental Pengaruh Sudut Kemiringan Modul Surya 50 Watt Peak Dengan Posisi Mengikuti Pergerakan Arah Matahari. Jurnal Skripsi Universitas Diponegoro : Semarang.

Fitriadi Saputra. 2015. Kinerja Pompa Air DC Berdasarkan Intensitas Tenaga Surya. Jurnal Skripsi Universitas Muhammadiyah Surakarta : Surakarta.

Muhammad Nafis Rahman. 2014. Modifikasi Sistem Penyemprotan Untuk Pengendalian Gulma Menggunakan Sprayer Gendong Elektrik. Jurnal Skripsi Institut Pertanian Bogor : Bogor.

Owen Bishop. 2004. Dasar-Dasar Elektronika. Erlangga : Jakarta
Pangestuningtyas D.L., Hermawan, Karnoto. 2013. Analisis Sudut Kemiringan Panel Surya Terhadap Radiasi Matahari Yang Diterima Oleh Panel Surya Array Tetap. Jurnal Skripsi Universitas Diponegoro : Semarang.

S. Tamimi, W. Indrasari, B. H. Iswanto. 2016. Optimasi Sudut Kemiringan Panel Surya Pada Prototipe Sistem Penjejak Matahari Aktif. Jurnal Skripsi Universitas Negeri Jakarta : Jakarta. 